Dermatology

Psychosomatics

Dermatologie

Psychosomatik
Letter to the Editors - Brief an die Herausgeber

Dermatol Psychosom 2001;2:203-204

\section{A Note from the Editors}

Dermatology + Psychosomatics is a journal dedicated to a high scientific standard. Therefore, a review process is a prerequisite for publication of manuscripts. Nevertheless, the editors of the journal feel the need to offer a platform for comments which can be printed without the demand for corrections and adaptation to rather formalistic criteria. To provide the opportunity for the presentation of 'methodologically unstandardized' spontaneous observations in clinical practice / of clinical experience or comments concerning previously published articles we start the new section 'Letters to the Editors' to hereby encourage the interaction among psychodermatology researchers and clinical practitioners. We would be pleased to promote a discussion within the context of psychodermatological issues in a broad sense and to contribute to interdisciplinary discussions.

Furthermore, the section 'Letters to the Editors' can be used to give feedback on articles published in the latest issues of the journal. We are grateful for comments with respect to methodological aspects of the treatises as well as to the results or conclusions drawn by the authors.

We hope that the new section will be taken up with interest and will contribute to a lively and interesting discussion. Last but not least we thank all colleagues and authors for their encouragement to include the new section.

The Editors

\title{
Trichotillomania and Deviation in the Socialization in Childhood
}

\author{
E. Manasievska ${ }^{a} \quad$ L. Pavlova ${ }^{\text {b }} \quad$ V. Jovanovska ${ }^{a} \quad$ L. Georgievska ${ }^{a}$ \\ aDepartment of Dermatology, Medical Center, Kumanovo \\ ${ }^{b}$ Clinic of Dermatology, University of Skopje, Macedonia
}

\section{Key Words}

Trichotillomania - Socialization in childhood .

Conversional neurosis

\section{Summary}

Trichotillomania is involuntary hair pulling, which may cause limited areas of irregular alopecia. It belongs to the conversion disorders, but can also be a result of a deviation in the socialization in childhood. In this paper a correlation is found between childrens's problems with adaptation to a new surrounding (kindergarten or infant school) and the appearance of trichotillomania. In 500 children (1-6 years of age) from 6 infant schools, among other adaptational problems, trichotillomania appears with 5 children: 4 boys and 1 girl (during a period of 1 year). The children were $2.5,3$, and 4 years old. Of these, 2 children managed to adapt to the new environment and 3 did not. The examined children were in the period of primary structuring of the basic functions of their personality. The problems with adaptation, manifested through trichotillomania, were results of previous negative experiences in the family: the children had anxieties because of physical and psychical addiction to the mother, or concerning punishment, or threats of being abandoned).

\section{KARGER \\ (ㅇ) 2001 S. Karger GmbH, Freiburg \\ Fax +497614520714 \\ Accessible online at: \\ E-mail Information@Karger.de www.karger.com/journals/dps \\ www.karger.com}

Dr. Emilija Manasievska

Medical Center - Kumanovo

Boris Kidric bb

MK-1300 Kumanovo (Macedonia)

E-mail emilija@sonet.com.mk 


\section{Introduction}

Trichotillomania is unintentional hair pulling which may lead to a remarkable loss of hair. It represents a disturbance in the control of habits and impulses and is characterized by repetition of actions without having a clear and rational motivation, thus causing damage to the patient as well as other people. The patient experiences the impulses as neither controllable nor preventable: they are imposed impulsively and must be fulfilled. The patient feels anxiety that increases to an unbearable limit, when the impulse is accomplished the results is satisfaction and relief.

Trichotillomania in childhood may be caused by a disturbance in the normal process of socialization, that is, a disturbance in the process of accepting fundamental habits. Each step in socialization is followed by a series of frustrations of the child's needs or whishes. Instead, the child gets fulfillment in the aspect of social affirmation such as: 'the child is obedient', or 'the child is neat and clean'. However, if the needs are inaccessible for the consciousness of the child, the conflicts resulting from frustration may initiate distortion of habit, and defense mechanisms are manifested in various different habits.

\section{Methods}

Included in this study were 500 children, aged 1-6 years, in 6 kindergartens in Kumanovo. Our aim was to find a relation between problematical socialization and trichotillomania. During 1 year, 5 children (4 boys and 1 girl) developed trichotillomania at the age of $2.5,3$, or 4 years. Trichotillomania appeared to be the visible manifestation of their inability to adapt to the new environment. Of these children 3 could not cope with the change of environment and have left the kindergarten, while 2 have managed to adapt. These 2 children were further examined using psychological interviews and genograms.

\section{Results}

Several common elements could be noticed during the analysis of the interviews and genograms:

- With children suffering from trichotillomania, in their early psychomotor development a period of whirling the hair or putting it in the mouth when they are excited or they want to calm down is observed.

- Their families of origin are basically dysfunctional with distorted roles of parents: dominant mother and passive father. Messages towards the child are not clear enough. The mother is strict in her demands towards the child.
- These children are seemingly quiet, well-adjusted, obedient, and accept the demands without any objections. But in conflict situations their need to be relieved of their anxiety in a very aggressive way is stressed.

- They have an ambivalent relation of love towards their mother, as well as passive resistance towards accomplishing her demands.

- Parents show little insight of the child's mental condition, as well as reluctance to accept that the cause of trichotillomania is of psychic nature.

- Parents do not have a positive attitude towards separation from their child and its involvement wider social environment.

\section{Conclusion}

Our study shows that trichotillomania can be a manifestation of disturbed socialization in childhood (pre-school age). In this age, children are in the period of fundamental creation of basic functions of their personality. Children with trichotillomania have problems adapting to a new surrounding, which is probably the result of a negative experience in the family. They are burdened with great anxiety, insecurity, dependency (physical and mental), punishments and threats that they will be separated from their parents.

The role of the mother for these children should also be stressed. She often tends to keep the children in a symbiotic relation and is not capable of regarding her child as an individual separated from her. In these families the mother is the more dominant figure in relation to the father. In such an atmosphere, chronic fear develops with feelings of constant endangerment; every moment separation and loss of protection might happen. Therefore, separation of the child from its family by being sent to kindergarten is a moment when the defense mechanisms of the child, among which is trichotillomania, are activated.

\section{References}

1 Karadaglic DJ: Dermatologija. Beograd, Vojnoizdavacki zavod, Versalpress, 2000, pp 676-679.

2 Ancevski A: Bolesti na kosa. Skopje, Jugoreklam, 1993, pp 134-135.

3 Meischer G, Schmuziger P: Trichomalacie und Trichotillomanie. Dermatologica 1957;114:199-206.

4 Rook A, Dawber R (eds): Diseases of the Hair and Scalp. London, Blackwell, 1991.

5 Warmbrodt L, Hardy RE, Chrisman SK: Understanding trichotillomania. J Psychosoc Nurs Ment Health Serv 1996;34:11-15. 